\title{
THE ROLE OF CONSUMER SATISFACTION IN MEDIATING THE EFFECT OF PERCEIVED SERVICE QUALITY AND BRAND IMAGE ON REPURCHASE INTENTION
}

\author{
Pratama Andhika Bukti ${ }^{*}$, Giantari I Gusti Ayu Ketut \\ Faculty of Economics and Business, University of Udayana, Bali, Indonesia \\ ${ }^{\star}$ E-mail: andhikabuktipratama@gmail.com
}

\begin{abstract}
The purpose of this study is to explain the role of consumer satisfaction in mediating the effect of perceived service quality and brand image on repurchase intentions. In this study, the criteria for respondents are people who live in Denpasar City, have made repeat purchases within a period of six months at least once, and have a minimum education of high school; the number of research samples is 128 respondents. The sampling technique used PLS-based SEM. The results showed that the perceived service quality had a positive but insignificant effect on repurchase intentions, brand image, and consumer satisfaction had a positive and significant effect on repurchase intentions, and the role of consumer satisfaction was able to perfectly mediate the effect of perceived service quality and brand image on repurchase intentions. The theoretical implications of this can contribute to the existing literature, especially regarding perceptions of service quality, brand image, consumer satisfaction and repurchase intentions at fast food restaurants. The practical implications of this study are expected to be able to contribute and understand the management of KFC fast food, especially in Denpasar City, regarding how consumer satisfaction mediates perceptions of service quality and brand image on repurchase intentions, so as to create purchase intentions.
\end{abstract}

\section{KEY WORDS}

Perceived service quality, brand image, consumer satisfaction, repurchase intention.

In the era of globalization, the business world is growing very rapidly; one of the businesses that is currently developing is the culinary business. This culinary business is related to human food needs which are one of the physiological needs. Physiological needs are the most basic hierarchy of human needs which are the needs to be able to live including clothing, food, shelter such as eating, drinking, housing, sleeping, and so on (Sari and Dwiarti, 2018). However, for the first time since Indonesia experienced the monetary crisis in 1998 , the growth of the food and beverage industry experienced a slowdown, this was the impact of the Large-Scale Social Restrictions (PSBB) policy to prevent the spread of the COVID-19 pandemic. This PSBB policy directly reduces economic activity and has an impact on many industrial sectors, including the food and beverage industry sector (bisnis.com). The food industry is currently increasingly in demand, one of which is the fast food restaurant franchise business. The business competition for fast food companies is currently getting fiercer, as each company's business expansion expands market share (kontan.co.id).

The fast food restaurant franchise business is currently growing in many cities, especially in big cities, many fast food restaurant franchises such as KFC, McDonald's, Hoka-Hoka Bento, A\&W, and Richeese Factory. This can be seen in the TOP Brand Fast Food 2020, where the Top Brand is based on the results of research conducted to select the best brands by Indonesian customers conducted through a survey from the Frontier Group. The TOP brand index data shows that fast food restaurants are frequently visited, where KFC occupies the first position of all fast food restaurant brands in 2015-2020 followed by other fast food restaurant brands, namely McDonald's occupying the second position in 2015-2020, Hoka-Hoka Bento occupying the third position in $2015-2020$, A\&W occupied fourth position in 2015-2020, occupied fifth position in 2016 - 2020 Richeese Factory, where TOP Brand KFC in 2015 was 59.3\% and increased 10\% to 63.9\% in 2016, in 2017 
decreased by $3.5 \%$ to $60.4 \%$, in 2018 decreased by $17.7 \%$ to $42.7 \%$, in 2019 again decreased by $16.5 \%$ to $26.2 \%$. Judging from the TOP brand table data, KFC is said to be still the consumer's choice in choosing fast food restaurant products compared to other fast food product brands, it can be concluded that KFC has decreased in the TOP fast food restaurant brand but still ranks first in the fast food restaurant brand. KFC fast food revenue data for the 2018-2020 period on a quarterly basis also shows that from 2019 to 2020 there was a decline in revenue.

By looking at the decline in revenue from KFC fast food, it certainly needs to be evaluated in terms of consumer behavior towards repurchase intentions on KFC fast food products. This increasingly fierce competition in the food industry requires every producer to be sensitive to the progress of the times, technology and changes in the needs or tastes of their consumers. A producer must be able to know the needs and wants of consumers before launching a product. So that this will lead to consumer buying intentions for products at KFC fast food restaurants.

Seeing from the development of TOP brands and revenue from KFC fast food restaurants which have decreased, this business phenomenon becomes quite interesting for further research. This study begins by conducting a pre-survey of 30 respondents, where 22 respondents stated that they would make repeat purchases because the quality of service and brand image provided by KFC fast food restaurants made consumers feel happy and interested, but there were 8 other respondents who stated that they would not make a purchase. review of the KFC fast food restaurant where 8 respondents complained about the long service and often waiting for food, which is not in accordance with the concept of fast food. Based on consumer reviews on google reviews in Denpasar City, there are consumer complaints who complain about service rather than KFC, therefore the quality of service becomes interesting to study.

The increasingly fierce competition between fast food restaurants certainly makes restaurants have to make innovations; one of the things that can increase the revenue of fast food restaurants is the intention to repurchase. Repurchase intention is something that every businessman wants. Repurchase intention is the taste of each person which is the basis for choosing something, buying interest shows a tendency to prefer products with certain brands. Kotler and Keller (2018) where consumer decisions to buy products are influenced by the evaluation process of the value of a product. One important element that makes consumers repurchase is when consumers have a good perception of the service quality of the brand (Saintz, 2018). Repurchase intention can also be influenced by brand image, brand image can affect someone's repurchase interest (Sutopo and Oceani, 2017). One of the factors that make a consumer will make a purchase of a product is customer satisfaction. Consumer satisfaction can strengthen the relationship between the independent variable which is the perceived service quality to the dependent variable which is the repurchase intention (Saintz, 2018). Consumer satisfaction is also able to moderate and strengthen the influence of brand image on repurchase decisions (Suryani and Rosalina, 2019).

A consumer will certainly make a repurchase when the quality of service provided is in accordance with what the consumer wants. According to (Kotler and Keller, 2018) the perceived service quality is the totality of features and characteristics of a product or service that bears on its ability to satisfy stated or implied needs. (Kotler and Keller, 2018) define quality as all the characteristics and characteristics of a product or service that have an influence on the ability to satisfy various implied needs. Previous research conducted by (Saints, 2018) revealed that there is a positive relationship between perceived service quality and repurchase intentions. In addition, the perceived service quality at PT Agung Toyota Denpasar has a significant positive effect on repurchase intentions (Aryadhe and Rastini, 2016). Likewise in research conducted by (Ramadhan and Santosa, 2017); (Suryani and Rosalina, 2019) where the perceived service quality has a positive and significant effect on repurchase intentions. However, this is not supported by research conducted by (Rosita, 2016); (Foster, 2019); and (Pratiwi et al, 2020) where the perceived service quality has no positive and significant effect on repurchase intentions. 
To increase repurchase intention, of course, there is something that consumers pay attention to, one of which is brand image. The brand image of a product is one of the important aspects in considering buying a product. According to (Kotler and Keller, 2018) brand image is a consumer's understanding of the brand as a whole, consumer confidence in a particular brand and how consumers perceive a brand. Brand image describes the extrinsic nature of a product or service including the way in which the brand tries to meet the psychological or social needs of customers, a positive brand will make consumers like a product with the relevant brand in the future, while for producers a good brand image will hinder marketing activities. competitor. This is supported by research conducted by (Andriadi and Untarini, 2013) brand image simultaneously affects repurchase intention and a significant and positive influence which in the brand image consists of brand associations, brand image has a positive and significant effect also strengthened by research (Ain and Ratnasari, 2015) where a strong and positive brand image will increase consumers' repurchase intention, on the contrary if the brand image is not good, then repurchase intention will decrease. Research conducted by (Hadiono and Palumian, 2019) where brand image is one of the factors that influence a consumer's intention to make repurchase intentions, as well as research conducted by (Fahmie et al, 2020) where brand image is identified as having an effect on intention. repurchase where the presence of a brand image can increase repurchase intentions from consumers. Research conducted by (Wardhani et al., 2021) shows that brand image has a positive and significant effect on repurchase decisions. However, brand image on repurchase intention is not supported by research and (Wijayasari and Mahfudz, 2018); (Prasetya and Yulius, 2018); and (Mudiantono and Andhike, 2019), where brand image does not have a significant positive effect on buying interest.

Satisfaction obtained by consumers is one of the factors that make a consumer buy a product. According to (Kotler and Keller, 2018) consumer satisfaction is a feeling of pleasure or disappointment that arises after comparing the performance of the product thought to the expected performance (results). One of the elements that make consumers repurchase is when consumers are satisfied with the brand and customer satisfaction is something that companies must pay attention to (Saintz, 2018). Service quality has been shown to have a positive and significant effect on satisfaction, where the better the services provided by Métis, the higher customer satisfaction (Evirasanti et al, 2016). This is also supported by research conducted by (Astuti and Pastikarani, 2016); (Suryaatmaja et al, 2016); (Ramadan and Santosa, 2017); (Dawi et al, 2018); (Pereira et al, 2018); (Sanjaya and Yasa, 2018) who say that service quality has a positive and significant influence on consumer satisfaction. Brand image is an important contribution to customer satisfaction, this is in accordance with research conducted by (Lahap et al, 2016) where there is a positive and significant relationship between brand image and consumer satisfaction. This is also supported by research conducted by (David, 2014); (Sutopo and Oceani, 2017); (Saintz, 2018) and (Suryani and Rosalina, 2019) which say that brand image has a positive and significant effect on consumer satisfaction.

Repurchase intention made by consumers can certainly be created as a result of customer satisfaction. Consumer satisfaction has a positive and significant effect, supported by research conducted by (Imran, 2018) where there is a positive and significant influence between the influence of consumer satisfaction on repurchase interest at the Ayam Bakar Wong Solo Allaudin Restaurant, Makassar City. In a study conducted by (Putra and Dewi, 2019) Consumer satisfaction is a factor that can increase consumers' repurchase intentions. The variable of consumer satisfaction with repurchase intention is also supported and strengthened by research (Astuti and Pastikarani, 2016); (Rahmawati et al, 2018); and (Firdaus, 2020).

Based on the background, the hypothesis used in this study is as follows

- H1: Perceived service quality has a positive and insignificant effect on repurchase intention;

- H2: Brand image has a positive and significant effect on repurchase intention;

- H3: Perceived service quality has a positive and significant effect on customer satisfaction; 
- H4: Perceived service quality has a positive and significant effect on customer satisfaction;

- H5: Consumer satisfaction has a positive and significant effect on repurchase intention;

- H6: Consumer satisfaction is significantly able to mediate the effect of perceived service quality on repurchase intention;

- H7: Consumer satisfaction is significantly able to mediate the effect of brand image on repurchase intention.

\section{METHODS OF RESEARCH}

The research design of this study is a form of associative and causal research with quantitative methods. Associative research is research that aims to determine the effect of the relationship between two or more variables (Sugiyono, 2019). The independent variables in this study are perceptions of service quality (X1) and brand image (X2) and are mediated by consumer satisfaction (Y1), the dependent variable in this study is repurchase intention (Y2). Based on the method of investigation, the experimental research method is one of the quantitative methods, used if the research wants to find the effect of exogenous variables (treatment) on endogenous variables (outcomes) under controlled conditions (Sugiyono, 2019). This type of research used non-experimental research. The sampling technique in this study was purposive sampling, the data collection technique was in the form of distributing questionnaires to KFC consumers in Denpasar City. This study uses 16 indicators where the sample used is 128 respondents. The data analysis method used is statistical analysis and inferential statistics which are analyzed using the Smart-PLS program.

\section{RESULTS AND DISCUSSION}

Based on the results of the characteristics of the respondents in this study, the age of respondents was dominated by the age of $23-25$ years by $52.3 \%$ with gender dominated by women by $53.9 \%$, with education level dominated by $\mathrm{S} 1$ at $82.8 \%$.

Table 1 - Direct Effect Test Results

\begin{tabular}{lllll}
\hline & $\begin{array}{l}\text { Original Sample } \\
(\mathrm{O})\end{array}$ & $\begin{array}{l}\text { T Statistics } \\
(|\mathrm{O} / \mathrm{STDEV}|)\end{array}$ & $\mathrm{P}$ Values & Information \\
\hline $\begin{array}{l}\text { Perceived service quality (X1) } \\
->\text { Repurchase Intention (Y2) }\end{array}$ & 0,553 & 0,639 & 0,262 & Not significant \\
\hline $\begin{array}{l}\text { Perceived service quality (X1) } \\
\rightarrow \text { Consumer Satisfaction (Y1) }\end{array}$ & 0,440 & 5,095 & 0,000 & Significant \\
\hline $\begin{array}{l}\text { Brand Image (X2) } \\
\rightarrow \text { Repurchase Intention (Y2) }\end{array}$ & 0,330 & 4,149 & 0,000 & Significant \\
\hline $\begin{array}{l}\text { Brand Image (X2) } \\
\rightarrow \text { Consumer Satisfaction (Y1) }\end{array}$ & 0,413 & 4,792 & 0,000 & Significant \\
\hline $\begin{array}{l}\text { Consumer Satisfaction (Y1) } \\
\rightarrow \text { Repurchase Intention (Y2) }\end{array}$ & 0.521 & 5,925 & 0,000 & Significant \\
\hline
\end{tabular}

Source: Primary data, processed (2021).

Table 2 - Mediation Variable Test Results

\begin{tabular}{llllll}
\hline Variable Mediation & Effect & & & & Information \\
\cline { 2 - 5 } & $(\mathrm{A})$ & $(\mathrm{B})$ & $(\mathrm{C})$ & $(\mathrm{D})$ & \\
\hline $\begin{array}{l}\text { Perceived service quality (X1) } \\
\begin{array}{l}\rightarrow \text { Consumer Satisfaction (Y1) }> \\
\text { Repurchase Intention (Y2) }\end{array}\end{array}$ & 0,229 & 0,053 & 0,440 & 0,521 & Full Mediation \\
$\begin{array}{l}\text { Brand Image (X2) -> Satisfaction (Y1) } \\
\rightarrow \text { Repurchase Intention (Y2) }\end{array}$ & 0,215 & 0,330 & 0,413 & 0,521 & Partial Mediation \\
\hline
\end{tabular}

Source: Primary data, processed (2021). 


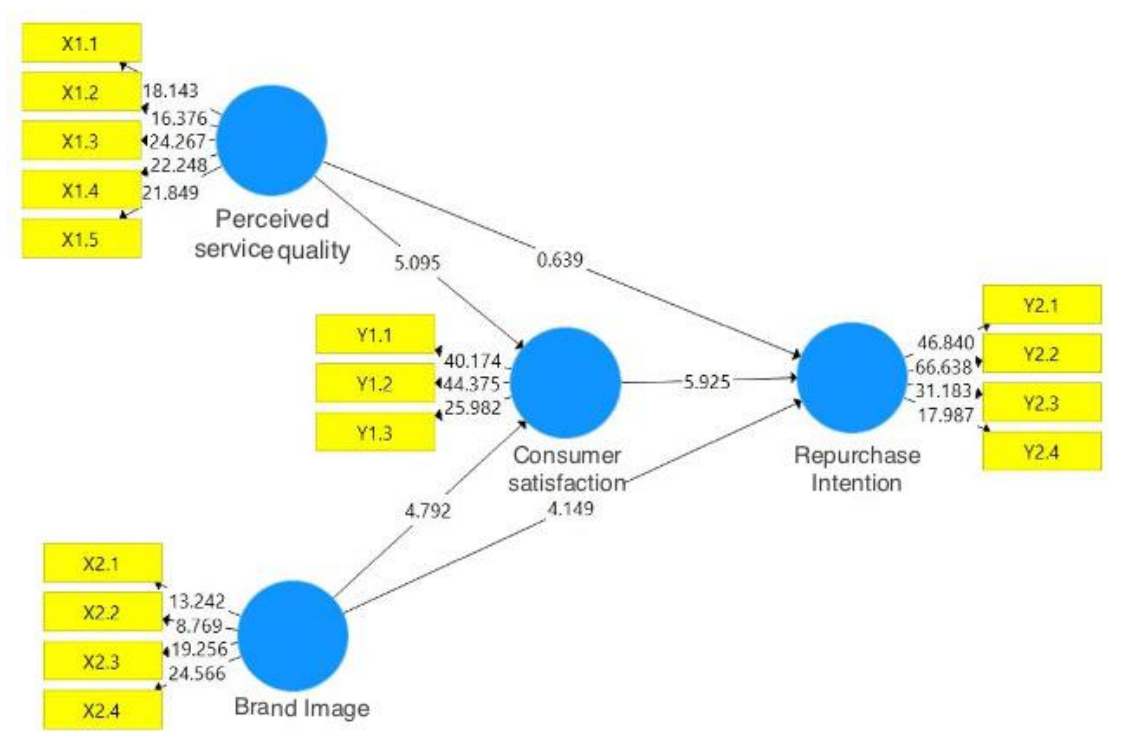

Figure 1 - Structural Model (Source: Primary data, processed in 2021)

The test results show that consumer satisfaction is able to mediate the effect of perceived service quality on repurchase intentions. Consumer satisfaction is able to fully mediate the effect of perceived service quality on repurchase intentions. This shows that the higher the perceived service quality will increase consumer satisfaction, then consumer satisfaction will increase repurchase intentions so that the perceived service quality can indirectly increase repurchase intentions. Consumer satisfaction is able to mediate the effect of brand image on repurchase intention. Consumer satisfaction is able to partially mediate the influence of brand image on repurchase intention. This shows that the higher the brand image, it can increase consumer satisfaction, so that in the end the repurchase intention will increase.

Table 3 - Direct Effects, Indirect Effects and VAF Results

\begin{tabular}{|c|c|c|}
\hline \multirow[t]{2}{*}{ Variable } & \multicolumn{2}{|l|}{ Direct effect } \\
\hline & Coef. Correlation & $t$-Statistics \\
\hline Perceived service quality (X1) -> Repurchase Intention (Y2) & 0,053 & 5,095 \\
\hline Perceived service quality $(\mathrm{X} 1)->$ Consumer Satisfaction $(\mathrm{Y} 1)$ & 0,440 & 0,639 \\
\hline Brand Image (X2) -> Repurchase Intention (Y2) & 0,330 & 4,149 \\
\hline Brand Image (X2) -> Consumer Satisfaction (Y1) & 0,413 & 4,792 \\
\hline Consumer Satisfaction (Y1) -> Repurchase Intention (Y2) & 0,521 & 5,925 \\
\hline Perceived service quality $(\mathrm{X} 1)$-> Consumer Satisfaction $(\mathrm{Y} 1)$-> Repurchase Intention (Y2) & 0,229 & 3,817 \\
\hline Brand Image (X2) -> Consumer Satisfaction (Y1) -> Repurchase Intention(Y2) & 0.215 & 3,824 \\
\hline Perceived service quality (X1) -> Repurchase Intention (Y2) & 0,282 & 3,046 \\
\hline Perceived service quality (X1) -> Consumer Satisfaction (Y1) & 0,440 & 5,095 \\
\hline Brand Image (X2) -> Repurchase Intention (Y2) & 0,545 & 6,469 \\
\hline Brand Image -> Consumer Satisfaction (Y1) & 0.413 & 4,792 \\
\hline \multirow[t]{2}{*}{ Consumer Satisfaction (Y1) -> Repurchase Intention (Y2) } & 0.521 & 5,925 \\
\hline & Nilai VAF & \\
\hline VAF - > Indirect effect / Total effect $(0.229 / 0,282)$ & 0,812 & \\
\hline VAF -> Indirect effect / Total effect $(0.215 / 0,545)$ & 0,394 & \\
\hline
\end{tabular}

Source: Primary data, processed (2021).

The coefficient value of the direct influence of perceived service quality on repurchase intention is 0.282 . The addition of the consumer satisfaction variable as a mediating variable has a different effect on the total perceived service quality with repurchase intentions, the VAF value is 0.812 . The mediation value of 81.2 percent is above 80 percent. This means that the variable is classified as a full mediation variable. In conclusion, the results in this study indicate that consumer satisfaction can fully mediate the effect of perceived service quality on repurchase intentions. the coefficient value of the direct influence of brand image on repurchase intention is $\mathbf{0 . 5 4 5}$. The addition of the consumer satisfaction variable as a 
mediating variable has a different effect on the total effect of brand image with repurchase intention. The VAF value is 0.394 . The mediation value of 39.4 percent is in the range of 20 percent to 80 percent. This means that the variable is classified as a partial mediation variable. In conclusion, the results in this study indicate that consumer satisfaction can partially mediate the effect of brand image on repurchase intention.

The effect of perceived service quality on repurchase intentions shows that perceived service quality has a positive and insignificant effect on repurchase intentions on consumers of KFC fast food restaurants in Denpasar. This means that the consumer's repurchase intention of KFC fast food restaurants cannot be explained by the perceived service quality or in other words the quality of service has no effect on repurchase intentions. The perceived service quality referred to in this study is the experience experienced by consumers in feeling the quality of service provided by KFC fast food restaurants. Based on the measurement results, it is found that service courtesy is the strongest indicator in reflecting perceptions of service quality with an average of 4.26 . This result is also supported by 100 percent of respondents who have made purchases more than twice in the last six months. When it is associated with the characteristics of the respondents where there are 52.3 percent aged 2325 and the majority are already working, where the strategic location of KFC, the taste is convincing and the food that is considered practical are the factors desired by a worker. Perceived service quality as measured by outer loading on indicators: the ability to carry out the promised service accurately, the ability to provide services quickly, politeness of service, knowledge of service to customers and the ability to convince customers. This finding can be interpreted that the perceived service quality is not necessarily able to provide a significant contribution in increasing repurchase intentions at KFC fast food restaurants. The results of this study are in accordance with the results of previous research by Pratiwi et al. (2020) which states that the perceived service quality has a positive but not significant effect on repurchase intentions on Teras Atas Café consumers. Research by Rosita (2016), Foster (2019) which states that the perceived service quality has a positive but not significant effect on repurchase intentions. However, the results of this study contradict previous studies conducted by Aryadhe and Rastini (2016), Ramadhan and Santosa (2017), Wiratama et al. (2017) and Saintz (2018) which state that the perceived service quality has a positive and significant effect on repurchase intentions.

The effect of brand image on repurchase intention shows that brand image has a positive and significant effect on repurchase intention. This means that the better the brand image of the KFC fast food restaurant, the higher the consumer's repurchase intention. Vice versa, the lower the brand image of the KFC fast food restaurant, the lower the intention to repurchase. These results indicate that the values contained in the brand image can be perceived well and have a real impact on the repurchase intention of KFC fast food restaurants. Brand image with the highest indicator, namely a good impression in the minds of consumers in this study, is able to increase repurchase intentions of KFC consumers. This means that the impression of the image of KFC is able to influence consumers' repurchase intentions at KFC. With the image of KFC that is already known by many consumers, it can increase consumers' repurchase intentions at KFC fast food restaurants. The results of this study are in accordance with the results of previous research by Fahmi et al. (2020) where research conducted on 140 respondents at 5 Fast Food restaurants in Medan City showed that brand image had a positive and significant influence on repurchase intentions. The results of this study are in accordance with the results of previous studies by Ain and Ratnasari (2015), Sutopo and Oceani (2017), Hadiono and Palumian (2019), Sutrisna and Yasa (2021) which state that brand image has a significant positive effect on repurchase intention.

The effect of service quality on consumer satisfaction shows that the perceived service quality has a positive and significant effect on customer satisfaction. This means that the higher the perceived service quality of the KFC fast food restaurant, the more customer satisfaction will be. Vice versa, the lower the perception of the service quality of the KFC fast food restaurant, the lower the customer satisfaction. The perceived service quality as measured by the highest indicator, namely the courtesy of the service provided by KFC will 
certainly be able to make consumers feel satisfied because KFC is able to provide the need for norms politeness desired by consumers. This means that the perceived service quality is able to increase customer satisfaction at KFC fast food restaurants. The results of this study are in accordance with the results of previous research conducted by Sulistyawati and Seminari (2015) where service quality affects customer satisfaction at Indus Ubud restaurant, where this study was conducted on 105 respondents at Undus Ubud restaurant. This means that the better the service of a restaurant will increase the satisfaction of its customers. These results support the research conducted by (Dewi et al, 2014); (Ramadan and Santosa, 2017); (Dawi et al, 2018); (Sanjaya and Yasa, 2018).

The effect of brand image on consumer satisfaction shows that brand image has a positive and significant effect on consumer satisfaction. This means that the better the brand image of the KFC fast food restaurant, the higher the consumer satisfaction. Vice versa, the lower the brand image of the KFC fast food restaurant, the lower the consumer satisfaction. The brand image with the highest indicator, namely a good impression in the minds of consumers in this study was able to increase repurchase intentions on KFC consumers, where the image of KFC is high which can be seen based on TOP Brand Index data which shows that the KFC brand has always been the No. 1 choice in fast food restaurants, which can increase the satisfaction of KFC consumers because of a good brand image. The results of this study are in accordance with the results of previous studies by (Evirasanti et al, 2016) that service quality has a positive and significant effect on satisfaction, where the better the services provided by Métis, the higher customer satisfaction. These results support the research conducted by (Yulianti et al, 2014); (Astuti and Pastikarani, 2016); (Ramadan and Santosa, 2017); (Dawi et al, 2018); (Diputra and Yasa, 2021) who say that service quality has a positive and significant influence on consumer satisfaction.

The effect of consumer satisfaction on repurchase intentions shows that consumer satisfaction has a positive and significant effect on repurchase intentions. This means that the higher the consumer satisfaction from the KFC fast food restaurant, the higher the consumer's repurchase intention. Vice versa, the lower the consumer satisfaction of the KFC fast food restaurant, the lower the intention to repurchase. Consumer satisfaction as measured by the highest indicator, namely the fulfillment of customer needs provided by KFC will certainly be able to make consumers recommend KFC to others because KFC is able to meet the needs of its consumers. This means that the more satisfied customers are, the more they can increase their repurchase intentions at KFC fast food restaurants. The results of this study are in accordance with research conducted by (Lahap et al, 2016) where there is a positive and significant relationship between brand image and consumer satisfaction. This research is also supported by research conducted by (Sutopo and Oceani, 2017); (Saintz, 2018); (Suryani and Rosalina, 2019) and (Hermawan and Yasa, 2021) who say that brand image has a positive and significant effect on consumer satisfaction.

Consumer satisfaction is able to mediate the effect of perceived service quality on repurchase intentions. Consumer satisfaction in this study is as a full mediation (full mediation). Based on these results, it can be interpreted that the higher the perceived perceived service quality, it can increase consumer satisfaction, so that in the end consumers' repurchase intentions will increase. The results of this study support previous studies by (Rizan and Andika, 2011) that there is a positive and significant influence between perceptions of service quality and customer satisfaction. This study strengthens the research conducted by (Astuti and Pastikarani, 2016); (Ramadhan and Santosa, 2017) which says that the perceived service quality has a positive and significant influence on consumer satisfaction. positively and significantly to customer satisfaction. Consumers will certainly feel satisfied when the services provided are maximal, with satisfied consumers, of course, they will support consumers to repurchase (Imran, 2018). This is further strengthened by research conducted by (Astuti and Pastikarani, 2016); (Ramadhan and Santosa, 2017) which says that the perceived service quality has a positive and significant influence on consumer satisfaction. The variable of consumer satisfaction with repurchase intention is also supported and strengthened by research (Astuti and Pastikarani, 2016); (Rahmawati et al., 2018); (Firdaus, 2020). 
Consumer satisfaction is able to mediate the effect of brand image on repurchase intention. Consumer satisfaction in this study is as partial mediation (partial mediation). Based on these results, it can be interpreted that the higher the perceived brand image, it can increase consumer satisfaction, so that in the end the consumer's repurchase intention will increase. The results of this study support previous studies by (David, 2014); (Ramadan and Santosa, 2017); (Saintz, 2018); (Astuti and Pastikarani, 2016); (Rahmawati et al., 2018) and (Firdaus, 2020). With a high brand image and satisfied consumers, it can increase repurchase intentions from consumers.

\section{CONCLUSION}

Based on data analysis and discussion, the conclusion of this study is that the perceived service quality has a positive and insignificant effect on repurchase intention, this means that the perceived service quality is not necessarily able to increase the repurchase intention of KFC consumers. Brand image has a positive and significant effect on repurchase intention, this means that if the brand image increases, the repurchase intention of KFC consumers. The perceived service quality has a positive and significant effect on consumer satisfaction, this means that the better the perceived service quality, the repurchase intention of KFC fast food restaurant consumers is increasing. Brand image has a positive and significant effect on consumer satisfaction, this means that the better the brand image, the consumer's repurchase intention of KFC fast food restaurants is increasing. Consumer satisfaction has a positive and significant effect on repurchase intentions, this means that if consumers are satisfied, it can increase the repurchase intention of KFC consumers. Consumer satisfaction is able to mediate the effect of perceived service qualitys on KFC's repurchase intentions, this shows that KFC's consumer perceived service qualitys will have a significant impact on consumers' repurchase intentions if mediated by consumer satisfaction, which means that the perceived service quality is highly dependent on the level of satisfaction. perceived by consumers and repurchase intention. Consumer satisfaction is able to mediate the effect of brand image on KFC's repurchase intention, this shows that perceived brand image will have a significant impact on consumers' repurchase intentions if mediated by consumer satisfaction, which means that the perceived service quality is highly dependent on the level of satisfaction felt by consumers. and intention to repurchase.

Based on the results of research analysis, discussion and conclusions, there are several suggestions that can be used as consideration in determining policies related to maintaining and increasing repurchase intentions at KFC fast food restaurants in the future, among others, by improving good service quality, it is recommended that the management provide good service. quickly to consumers, in order to conform to the concept of a fast food restaurant where fast service should be one of the characteristics of a fast food restaurant. KFC can improve the standard in providing services so that consumers are increasingly interested in making repeat purchases, furthermore in improving the brand image of KFC fast food restaurant consumers, it is recommended for KFC management to make offers such as promos or food packages to consumers so as to form high repurchase intentions. to consumers and the next suggestion is to be able to increase consumer satisfaction for KFC fast food restaurants, it is recommended for KFC management to increase satisfaction in terms of responding to complaints experienced by consumers so as to increase high repurchase intentions to consumers because consumers are satisfied with the responsiveness of KFC . KFC can increase consumer satisfaction by adding a complaint report feature to the WhatsApp messenger feature that has been widely used, making it easier for consumers to report complaints.

\section{REFERENCES}

1. Ain, N., and Ratnasari, R.T. 2015. Pengaruh Citra Merek Melalui Sikap Konsumen Terhadap Niat Beli Ulang Pada Produk Busana Muslim Zoya Di Surabaya, JESTT, Vol. 2, No. 1. pp. 553-569. 
2. Andriadi, A., and Untarini, N. 2013. Pengaruh Persepsi Kualitas Layanan and Citra Merek Telkom Flexi Terhadap Niat Beli Ulang. Jurnal Ilmu Manajemen, Vol. 1, No. 2. pp. 639649.

3. Aryadhe, P., and Rastini, N.M. 2016. Kualitas Pelayanan, Kualitas Produk and Citra Merek Terhadap Niat Beli Ulang Di PT Agung Toyota Denpasar, E-Jurnal Manajemen Unud, Vol. 5, No. 9. pp. 5695-5721.

4. Astuti, S.R.T., and Pastikarani, D.A. 2016. Analisis Pengaruh Faktor-Faktor Minat Beli Ulang dengan Kepuasan Pelanggan Sebagai Variabel Intervening, Diponegoro Journal Of Management, Vol. 5, No. 2. pp. 1-9.

5. Dawi, N. M., Jusoh, A., Streimikis, J., and Mardani, A. (2018). The influence of service quality on customer satisfaction and customer behavioral intentions by moderating role of switching barriers in satellite pay TV market, Economics and Sociology, Vol. 11, No. 4. pp. 192-218.

6. Dewi, G.A.P.R.K., Yasa, N.N.K., and Sukaatmadja, P.G. 2014. Pengaruh Kualitas Pelayanan Terhadap Kepuasan and Loyaliyas Nasabah PT. BPR Hoki di Kabupaten Tabanan, E-Jurnal Ekonomi and Bisnis Universitas Udayana, pp. 257-275.

7. Diputra, I.G.N.A.W.M., and Yasa, N.N.K. 2021. The Influence Of Product Quality, Brand Image, Brand Trust On Customer Satisfaction And Loyalty, American International Journal Of Business Management, Vol. 4, No. 1. pp. 25-34.

8. Evirasanti, M., Rahyuda, K., and Yasa, N.N.K. 2016. Pengaruh Kualitas Layanan Terhadap Kepuasan Pengaruh Kepuasan Terhadap Niat Beli Kembali, E-Jurnal Ekonomi and Bisnis Universitas Udayana, Vol. 5, No. 12. pp. 4331-4358.

9. Fahmi, M., Arif, M., Farisi, S., and Purnama, N.I. 2020. Peran Brand Image dalam Memediasi Pengaruh Social Media Marketing terhadap Repeat Purchase pada FastFood Restaurant di Kota Medan, Jurnal Samudra Ekonomi and Bisnis, Vol. 11, No. 1. pp. 53-68.

10. Firdaus. 2020. Pengaruh Persepsi and Kepuasan Pelanggan Terhadap Minat Pembelian Ulang Produk Private Label Indomaret, Jurnal Manajemen Terapan and Keuangan, Vol. 9, No. 1. pp. 1-14.

11. Foster, B. 2019. Self Image Congruity and Customer Perceived Sq On Impact Satisfaction On Repurchase Intention, Journal Sampurasun: Interdisciplinary Studies for Cultural Heritage, Vol. 5, No. 1. pp. 39-52.

12. Hadiono, N., and Palumian, Y. 2019. Pengaruh Fasilitas and Citra Merek Terhadap Niat Pembelian Ulang Produk Starbucks Di Surabaya, AGORA, Vol. 7, No. 2. pp. 1-11.

13. Hermawan, A., and Yasa, N.N.K. 2021. The Effect Of Store Atmosphere, Promotion, And Retail Service On Customer Satisfaction And Repurchase Intention, European Journal Of Business And Management, Vol. 13, No. 8. pp. 160-169.

14. Imran, M.A. 2018. Pengaruh Kepuasan Pelanggan Terhadap Minat Beli Ulang Makanan Di Rumah Makan Ayam Bakar Wong Solo Alauddin Kota Makassar. Jurnal Profitability Fakultas Ekonomi and Bisnis, 2(1):50-64.

15. Kotler, P., and Keller, K. L. 2018. Marketing Management. 15th Edition. New Jersey: Pearson.

16. Lahap, J., Ramli, N.S., Said., N.M., Radzi, S.M., and Zain, R.A. 2016. A Study of Brand Image towards Customer's Satisfaction in the Malaysian Hotel Industry , Procedia Social and Behavioral Sciences, pp. 149-157

17. Mudiantono., and Andhike, D. 2019. Factors Influencing Customer's Repurchase Intention Of Go-Jek In Semarang, Indonesia, INOBIS, Vol. 2, No. 4. pp. 458-472.

18. Pereira, D., Giantari, N.G.K., and Sukaatmadja, I.P.G. Pengaruh Service Quality Terhadap Satisfaction and Customer Loyalty Koperasi Dadirah Di Dili Timor Leste. EJurnal Ekonomi and Bisnis Universitas Udayana. pp. 455-458.

19. Pratiwi, R.S., Soebandi, S., and Dharmani, I.G.A.A.N. 2020. The Influence of Service Quality, Price Perception, and Store Atmosphere on Repurchase Intention (Case Study at The Teras Atas Cafe Surabaya), Quantitative Economics and Management Studies, Vol. 1, No. 2. pp. 1-10. 
20. Prasetya, W., and Yulius, C. 2018. Pengaruh Kualitas Produk and Citra Merek Terhadap Kepuasan Konsumen and Minat Beli Ulang, Jurnal Teknologi, Vol.11, No. 2. pp. 92-100.

21. Putra, I.B.P., and Kusumadewi, N.W.M. 2019. Pengaruh Inovasi Produk Terhadap Niat Pembelian Ulang Dimediasi Oleh Kepuasan Pelanggan, E-Jurnal Manajemen , Vol. 8, No. 8. pp. 4983-5006.

22. Rahmawati, A.P., Prihastuti, R., and Azis, A. 2018. Pengaruh Kepuasan Pelanggan Terhadap Repurchase Intention, Jurnal Psikologi IImiah, Vol. 10, No. 3. pp. 293-298.

23. Ramadhan, G.A., and Santosa, S.B. 2017. Analisis Pengaruh Kualitas Produk, Kualitas Pelayanan, and Citra Merek Terhadap Minat Beli Ulang Pada Sepatu Nike Running Di Semarang Melalui Kepuasan Pelanggan Sebagai Variabel Intervening, Diponegoro Journal Of Management, Vol. 6, No. 1. pp. 1-12.

24. Rosita, R. 2016. Pengaruh Lokasi, Kelengkapan Produk, Kualitas Produk, Pelayanan, Harga, and Kenyamanan Berbelanja Terhadap Minat Beli Ulang Konsumen Pada Lotte Mart Bekasi Junction, Jurnal Ilmiah Widya Ekonomika, Vol. 1, No. 2. pp. 98-103.

25. Saintz, J. 2018. Pengaruh Perceived Service Quality Terhadap Repurchase and Customer Satisfaction Sebagai Variabel Intervening Pada Fast Food Restaurant Di Surabaya, Jurnal Manajemen Pemasaran, Vol. 12, No. 2. pp. 77-83.

26. Sanjaya, D.P.W., and Yasa, N.N.K. 2018. The Effect Of Service Quality On Customer Satisfaction, Positive Word Of Mouth And Corporate Image, Journal Of Business And Management, Vol. 20, No. 7. pp. 28-33.

27. Sari, E., and Dwiarti, R. 2018. Pendekatan Hierarki Abraham Maslow Pada Prestasi Kerja Karyawan PT. Madubaru (Pg Madukismo) Yogyakarta. JPSB, 6(1):68-77.

28. Sugiyono. 2019. Metode Penelitian Kuantitatif, Kualitatif and R\&D. Bandung: Alfabeta.

29. Sulistyawati, N.M.A., and Seminari, N.K. 2015. Pengaruh Kualitas Pelayanan Terhadap Kepuasan Pelanggan Restoran Indus Ubud Gianyar, E-Jurnal Manajemen Unud, Vol. 4, No. 8. pp. 2318-2332.

30. Suryaatmaja, A.N., Suprapti, N.W.S., and Yasa, N.N.K. 2016. Pengaruh Kualitas Pelayanan and Citra Terhadap Kepuasan and Word Of Mouth Nasabah, E- Jurnal Ekonomi and Bisnis Universitas Udayana, Vol. 5, No. 7. pp. 2191-2210.

31. Suryani, S., and Rosalina, S.S. 2019. Pengaruh Brand Image, Brand Trust, and Kualitas Layanan Terhadap Keputusan Pembelian Ulang Dengan Kepuasan Pelanggan Sebagai Variabel Moderating, Journal Of Business Studies, Vol. 4, No. 1. pp. 41-53.

32. Sutrisna, I.K.G.W., and Yasa, N.N.K. 2021. The Role of Brand Image in Mediating the Effect of Product Quality Towards Repurchase Intention at "Umah Lokal" Coffee Shop, American International Journal of Business and Management, Vol. 4, No. 2. pp. 1-17.

33. Sutopo., and Oceani. 2017. Analisis Pengaruh Citra Merek, Nilai Pelanggan, and Kepuasan Pelanggan Terhadap Minat Beli Ulang Pelanggan Tupperware Di Magelang. Diponegoro Journal of Management, Vol. 6, No. 1. pp. 1-13.

34. Wardhani, M.K., Sudarwati.,dan DPW, I.A. 2021. Keputusan Pembelian Ulang Ditinjau Dari Citra Merek, Media Iklan, and Brand Trust Pada Produk Imboost Di Surakarta, Jurnal IImiah Edunomika, Vol. 5, No. 1. pp. 224-234.

35. Wijayasari, N., and Mahfudz. 2018. Pengaruh Brand Image, Kualitas, Persepsi Harga and Variasi Produk Terhadap Minat Beli Konsumen Sarung Gajah Duduk Di Kabupaten Pekalongan, Diponegoro Journal Of Management, Vol. 7, No. 2. pp. 1-9.

36. Wiratama, I.G., Rahyuda, K., and Yasa, N.N.K. 2017. Pengaruh Citra Toko and Kualitas Pelayanan Terhadap Kepercayaan Pelanggan Serta Niat Beli Produk Private Label Alfamart. Buletin Studi Ekonomi, Vol. 22, No. 22. pp. 239-249.

37. Yulianti, N.M.D.R., Suprapti, N.W.S., and Yasa, N.N.K. 2014. Pengaruh Citra Toko Terhadap Kepuasan Pelanggan and Niat Beli Ulang Pada Circle K Di Kota Denpasar, Jurnal Manajemen Strategi Bisnis and Kewirausahaan, Vol. 8, No. 1. pp. 36-44.

38. https://ekonomi.bisnis.com/read/20201105/9/1314226/pecah-rekor-dalam-22-tahunekonomi-indonesia-resesi-digerogoti-corona (Diakses pada tanggal 1 Februari 2021)

39. https://industri.kontan.co.id/news/persaingan-bisnis-makanan-siap-saji-semakin-ketat (Diakses pada tanggal 1 Februari 2021). 